\title{
Narrative Strategies and Aesthetic Ethics of Nabokovian Otherworld in Lolita and Pale Fire
}

\author{
Juan Wu \\ School of Foreign Language, Beijing Institute of Technology, Beijing, China
}

\begin{abstract}
This paper demonstrates the rhetoric technique, narrative function and sign decoding of Nabokocian otherworld in Lolita and Pale Fire to detect not only the presence of the metaphysical otherworld, but also the faint influence upon the living. Under the narrative strategies of the otherworld lies Nabokov's aesthetic ethics, which make those who label Nabokov pessimistic and indifferent to be aware of his persistent attempt to push beyond the boundaries of human consciousness and his sincere concern and deep sympathy for the misery of men.
\end{abstract}

Keywords: Nabokov, narrative strategies, aesthetic ethics, otherworld, Lolita, Pale Fire

\section{Introduction}

Vladimir Nabokov is generally acknowledged as a distinctive figure in the history of the twentieth-century American literature, as novelist, poet, scholar, translator and lepidopterists at the same time. Of all the works of Nabokov, Lolita (Nabokov, 1955) and Pale Fire (Nabokov, 1989) are the most intricately-designed, the most odd-structured works and have received widespread critical and popular acclaim. Numerous articles and books have contributed to commenting on them from various perspectives which mainly comprise its treatment of the art, postmodern features, narrative technique, cultural reflection, language characteristics and so forth. Almost all of these approaches focus on the artistic feature of his art and ignore the metaphysical and moral aspect of his work to some degree.

As Sontag suggests, "The function of criticism should be to show how it is what it is, even that it is what it is, rather than to what it mean" (1992, p. 55), this paper attempts to demonstrate that in Lolita and Pale Fire the characters who die do not simply disappear. Not only can the presence of their ghosts be detected, the faint influence of their spirits upon the living can also be discerned. Though Nabokov treats the ghostly activity as faintly as possible in his written world, yet the careful reader can not fail to find sufficient evidence to detect the almost invisible ghostly presences and influences. Underlying the metaphysical presence of the supernatural elements lying Nabokov's persistent attempt to push beyond the boundaries of human consciousness and his sincere concern and deep sympathy for the misery of men, rebuts those who label Nabokov pessimistic and indifferent towards the world.

Juan Wu, Lecturer, School of Foreign Language, Beijing Institute of Technology; Academic Visitor of Faculty of English Language and Literature, University of Oxford (2015-2016). 


\section{Statements and Significance of Nabokovian Otherworld}

Jacques Derrida declares “A masterpiece always moves, by definition, in the manner of a ghost” (Derrida, 1994, p. 18). Nabokov himself has an intense interest in the subject of ghost in the afterlife. The term of the "otherworld", a noun derived from an adjective denoting a quality or state that pertains to the "other side" or the "phantom" of the boundary separating life and death. Nabokov is so obsessed with the experience of death, in particular, he wants to know if their deaths reveal any information about the nature of the afterlife. In his novels Ada, Bend Sinister, The Defense, Despair, Invitation to a Beheading, Laughter in the Dark, Lolita, Look at the Harlequins!, Pale Fire, Speak Memory and Strong Opinions, Nabokov makes a great number of various statements about ghosts, their probable thoughts and emotions, the possible state of the afterlife and the imaginary process of dying. In Speak Memory, Nabokov declares: "Over and over again, my mind has made colossal efforts to distinguish the faintest of personal glimmers in the impersonal darkness on both sides of my life” (Nabokov, 1989, p. 20). Another important statement regarding Nabokov's otherworldly beliefs can be found in his lecture "The Art of Literature and Commonsense" which was published posthumously in 1980, and which is a revealing expression of his faith in a transcendental realm (Nabokov, 1980, p. 371).

As Nicolas Abraham holds,

The phantom, whatever its form, is nothing but an invention of the living. Yes, an invention in the sense that the phantom is meant to objectify, even if under the guise of individual or collective hallucinations, the gap the concealment of some part of a loved one's life produced in us. The phantom is, therefore, also a metaphysical fact. Consequently, what haunts are not the dead, but the gaps left within us by the secrets of others. (Abraham, 1987, p. 287)

Nabokov has occasionally revealed, in his novel or an interview, that the ghosts of his deceased characters influence the living or perhaps even act through them. Nabokov himself has admitted that his diverse books are very similar in many ways and several of the apparently isolated ideas about ghosts or whatever in his individual works instructively apply to others.

Besides, the centrality of the "hereafter" for Nabokov's art was announced by his wife in her Foreword to the posthumous collection of his Russican poems published in 1979. In her brief but seminal remark, Mrs. Vera Nabokov has called attention to a "main theme" in Nabokov's works, "potustoronnost", a word which Nabokov himself translated in English as "the hereafter". For Nabokov, potustoronnost is "a mystery that he carries in his soul"; it is what "give him his imperturbable love of life and lucidity even during life's most difficult trials". Nabokov came "closest of all” to this theme, wrote Mrs. Nabokov, "in the poem 'Frame', where he defined it completely candidly as a secret which he bears in his soul and which he must not and cannot give away" (Nabokov, 1979b, p. 3).

Mrs. Nabokov then quoted from "Frame" two lines that Nabokov had translated as follows: "that main secret tra-ta-ta tra-ta-ta tra-ta—/ and I must not be over-explicit” (Nabokov, 1970, p. 111). "Frame” ends with these words: / But one day while disrupting the strata of sense/ and descending deep down to my wellspring/ I saw mirrored, besides my own self and the world,/Something else, something else, something else (Nabokov, 1970, p. 111). This "something else" is possibly associated with the presence and influence of ghost that faintly pervades Nabokov's writings. She stresses that although it "saturates everything he wrote”, it does not appear to have seen noted by anyone. She then names several poems from various periods of his life, and a passage from 
the novel The Gift, that express this theme with varying degrees of clarity.

Vera Nabokov was perhaps the first to state that the central fact of both Nabokov's life and art was something that could be characterized as an intuition about a transcendent realm of being. At the same time, her valuable revelation stresses the pitfalls involved in talking about it, because Nabokov believed that the mystery was ultimately incommunicable. In "the Art of Literature and Commonsense”, Nabokov speaks of an aspect of his faith,

That human life is but the first installment of the serial soul and that one's individual secret is not lost in the process of earthly dissolution, becomes something more than an optimistic conjecture, and even more than a matter of religious faith, when we remember that only commonsense rules immortality out. (Nabokov, 1973, p. 45)

In the light of this statement, any attempt to decode the mystery, in which he embodied it, is bound to betray it to some extent. However, the risk is unavoidable if one wishes to come close to the essence of his art.

Thus, it is necessary and possible to trace the complex pattern of ghostly activity in Nabokov's works. Nabokov conceals his ghosts by some diversionary techniques. Yet such patterns of disguising, when carefully detected by the reading and rereading, can strikingly help to locate the presence and influence of Nabokovian elusive ghosts, which rebuts those who consider Nabokov merely a master stylist—with few deep ideas and little compassion for his characters-will be persuaded to take another look.

\section{Rhetoric Technique of Nabokovian Otherworld}

Nabokov conceals his ghosts by some diversionary techniques, which seems quite in keeping with Nabokov's mode of thought. Not only was Nabokov, as mentioned above, continually interested in possible hereafters, but also his fondness for hiding the solution to a mystery within its presentation. Many of his characters ridicule or scoff in the form of skepticism, facetious remarks, and even serious speculations at the presence and influence of spirits. For example, in the Forward of Lolita, John Ray, Jr. reports that "no ghosts walk" (Nabokov, 1955, p. 6). Humbert tells us that he could not murder Charlotte because "her ghost would haunt me all my life” (Nabokov, 1955, p. 89). He also asks Charlotte not to hate him in her afterlife (Nabokov, 1955, p. 90) and admits to fearing “a ghost” (Nabokov, 1955, p. 130) the night of her death. Such remarks tend to give the reader the impression that ghosts cannot be taken seriously, and that even they do exit, they have been fully accounted for.

Typically, a character may suspect the presence of one ghost when actually it is another. For instance, Kinbote thinks that Hentzner's ghost may be warning of Hazel's death via a round let of light that it actually used by Maud's ghost to warn of Shade's death. The pattern even includes reacting to a ghost's influence in a way exactly opposite to what is desired. For example, Shade is delighted by Maud's ghost's desperate attempt to divert him from his own death.

Nabokov is also fond of having characters whose spirits will later appear naturally while still alive. This technique is perhaps more effective if a ghost is already present. For example, when Humbert observes Lolita smoking with strong resemblance to her mother, he describes Lolita by saying that "Charlotte Haze rose from her grave” (Nabokov, 1955, p. 90). Another technique is that Nabokov typically calls attention to notions about ghostly activity which are quite obvious false. For example, in Pale Fire, "The Vane Sisters” are so ridiculed told with the effect of diverting the reader's attention from genuine ghostly activity. What's more, Nabokov is fond of 
using words like "spirit", "ghost” at times when ghosts really are present. An example is Kinbote's observation that "Cedarn is now a ghost town" (Nabokov, 1955, p. 70).

The ghosts in Nabokov's works are quite naturally disguised by several characteristics of his writing: literary allusions, parodies, a great number of vivid details, complex patterns involving chess, butterfly and so on. Perhaps still more important, many of Nabokov's characters have a feeling of being influenced, or even manipulated, by a force that they consider to be Fate, as in The Gift, or McFate (Nabokov, 1955, p. 99) as Humbert calls it in Lolita.

Once a reader has detected the pattern, such phrases, expressions and techniques can become a form of decoding the ghostly presences and influences. First of all, the elusive spirits consistently appear in, or act through, certain backgrounds such as wind, rain, sunlight and water which are depicted in faintly unusual way. And these background elements often seem appropriate in agreement of the ghosts' personality and emotion just prior to death and their intentional objectives in trying to influence the living. What's more, there are some characteristic background details and phrases recurring throughout Nabokov's novels at times when ghosts are present. They are descriptions of sunsets and the low sun, illuminated or stain-glass windowpanes, and rising, whirling dust observed with a strange and unusual perspective.

In Lolita, lurking in wind and rain, Charlotte's spirit may be seen to exert a faint and constantly negative influence on the affair between Humbert and Lolita. Like Hermann in Despair (Nabokov, 1979a), Humbert in Lolita is not permitted to detect, in his own narration, the numerous presences and faint influences of Charlotte's spirit. But, after the death of Charlotte, when he intended to get Lolita, he noted the highly suggestive weather: "a sudden onslaught of wind, and a black thunderhead loomed above Ramsdale’s white church tower” (Nabokov, 1955, p. 105). Taking Charlotte's furious felling at the time of her sudden death and Humbert's vicious intention at that moment, the aggressive wind and looming thunderhead seem an appropriate suggestion of her hovering spirit. Humbert then adds: “A raindrop fell on my knuckles” (Nabokov, 1955, p. 105), which bears striking similarity in Look at the Harlequins!, Annett's spirit causes a hailstone to strike Vadim's bald spot just before he intends to be intimate with her daughter in a thunderstorm.

What's more, Humbert soon relates Jean Farlow's attempt to kiss him good-bye, as well as her darkly humorous suggestion, "kiss your daughter for me" (Nabokov, 1955, p. 106). At that moment, "a clap of thunder reverberated throughout the house" (Nabokov, 1955, p. 106) which is highly associated with the presence of Charlotte's spirit in the way that she is horrified at Jean's unwitting prediction and as Charlotte "was a little jealous of Jean” (Nabokov, 1955, p. 90), she has now attempted "to glue herself” (Nabokov, 1955, p. 106) to Humbert's lips.

When Humbert leaves for Lolita’s camp, the impending storm imagery associated with Charlotte's spirit becomes even more active and visible: "everything was whirling and flying before the approaching white deluge ... and dust was running and writhing over the exact slab of stone where Charlotte ... had been revealed" (Nabokov, 1955, p. 107).

Another example is that on the way to The Enchanted Hunters with Humbert, Lolita suddenly asks: "Say, wouldn't Mother be absolutely mad if she found out we were lovers?” (Nabokov, 1955, p. 116). Humbert pretends to be shocked at the idea, adding "I think we are going to have some more rain" (Nabokov, 1955, p. 116). They drive on under "a gloomy sky” through "a steady drizzle” (Nabokov, 1955, p. 116), and Humbert mentions 
"a kind of secondary fate ... pettily interfering" (Nabokov, 1955, p. 116) as he struggles to find the hotel. They then share a bed and become lovers on a "wet and windy night" (Nabokov, 1955, p. 132).

In Lolita, Charlotte's ghost acts through wind and stormy to exert influence on Humbert, the man is about to become intimate with her daughter. In Pale Fire, like Charlotte's spirit in Lolita, Shade’s spirit inflict negative influences via wind on Kinbote. Hazel Shade's spirit also acts through wind, which her grieving mother says she hates.

Shade's ghost would not be pleased by what Kinbote is doing to his poem. On the first page of his foreword, Kinbote abruptly remarks: "there is a very loud amusement park right in front of my present lodgings". The next page writes normally until Kinbote suggests that "our shadows still walk without us”, ending the sentence: “... and damn that music". Also in the Foreword, kinbote refers to "rotating, malicious music" (Nabokov, 1955, p. 11), and finally he mentions "that carrousel inside and outside my head" (Nabokov, 1955, p. 18). And later Kinbote reveals that "at first I was greatly bothered by the clare of diabolical radio music from what I thought was some kind of amusement park across the road-it turned out to be camping tourists” (Nabokov, 1955, p. 167). Kinbote then adds: "now it is quieter, except for an irritating wind rattling through the withered aspens, and cedarn is again a ghost town" (Nabokov, 1955, p. 167). Here, "the irritating wind" suggests the effort of interference of Shade's ghost, no longer able to act through the camping tourists' radio. And although Kinbote survives to have the "the last word" (Nabokov, 1955, p. 19), it seems quite probable that the influence of Shade's ghost eventually triumphs, as Nabokov has declared that Kinbote "committed suicide after putting the last touches to his edition of the poem” (Nabokov, 1989, p. 120).

The possibility that Shade's ghost lurks in the "irritating wind" is strengthened by the fact that his daughter Hazel's spirit also acts through wind. As with Oleg's ghost, the clues for detecting her spirit are explicitly given within the novel. However, Nabokov typically disguises the presence of Hazel's spirit by having Shade refer without conviction to "her ghost" (Nabokov, 1989, line 290). He also complicates matters by having Shade describe how he and his wife unsuccessfully searched for Hazel's ghost all around them. A "funny creaking" turns out to be a "shutter" (Nabokov, 1989, lines 653-654), and something that "glides down the roof" is sad to be “old winter” (Nabokov, 1989, lines 659-660). Other references are apparently more pertinent: "I hate the wind!" (Nabokov, 1989, line 656) and "it is a tendril fingering the pane" (Nabokov, 1989, line 658). These two comments do signal the presence of Hazel's ghost, which becomes evident if we return to the night of her suicide.

In Shade's poem, the focus shifts back and forth between Hazel and her parents on the night of her death. She arrives at the lake, while her mother turns off the television, causing "life to snap” (Nabokov, 1989, line 472). A watchman then appears: "Along the reedy bank. He came too late. / You gently yawned and stacked away your plate. /We heard the wind. We heard it rush and throw / Twigs at the windowpane” (Nabokov, 1989, line 489).

Although the Shades never realize it, "that wind!” and the "tendril fingering the pane" correspond exactly to these last two lines when she just died. Nabokovian ghosts often act through what is termed in Transparent Things "a breath of wind". A few lines later, in Shade’s poem, we read: "it was a night of thaw, a night of blow, / with great excitement in the air" (Nabokov, 1989, line 474). Here the wind is now very faintly personified. Also typically, there is faintly pun-like relationship between the name Hazel and the "twigs" that her ghost causes to strike the windowpane. Given the cumulative sadness of Hazel's life, we may detect a faint reproachful note in the fact that the wind "rushes" and "throws” the twigs at her parents' window. A final clue that Hazel's ghost 
returns to the Shades' house appears in Kinbote's rather devious Index: under "Hazel”, one finds "the domestic ghost” (Nabokov, 1989, p. 222).

In the two novels, the characters cannot be allowed to understand the implications of their associating these elemental forces with spirits. Yet here the careful reader can not fail to note these background elements are faintly and suitably personified. In Lolita, Charlotte's ghost acts through stormy. In Pale Fire, Shade's spirit inflicts negative influences via wind on Kinbote. Hazel Shade's spirit also acts through wind, which her grieving mother says she hate. In Nabokovian reality, they are characteristic background details when spirits are present.

\section{Narrative Function of Nabokovian Otherworld}

These after-life beings often concentrate their influence on some particular agencies, or act through some living person or induce dreams and recollections in which their former selves appear. Such dreams and recollections which cause a person to remember their former selves usually tend to be suggestive prophetic, surprisingly and extraordinary vivid.

In Lolita, Charlotte's spirit seems to attempt to promote Clare Quilty's association with Lolita, who eventually deprives Humbert of Lolita. At the Enchanted Hunters, Humbert leaves Lolita in their room and walks outside into "the soggy black night, full of ripple and stir" (Nabokov, 1955, p. 128). He then meets Quilty, who questions "where the devil did you get her?" by "the weather is getting better" (Nabokov, 1955, p. 128). And another of Quilty's question: “where’s her mother?” (Nabokov, 1955, p. 128) leads us the reader to suspect the presence of Charlotte's spirit. As mentioned above, Lolita's question about her mother was attended by the appearance of “more rain” (Nabokov, 1955, p. 128). Here, Charlotte's spirit seems to acts, as Humbert is about to see Quilty's face: "he struck a light, but because he was drunk, or because the wind was, the flame illumined not him but another person” (Nabokov, 1955, p. 128). Thus, Humbert fails to recognize this suspiciously inquisitive stranger, who had recently attracted Lolita in the dining room (Nabokov, 1955, p. 123) and who will torture Humbert and eventually steal Lolita.

Another question about Charlotte’s present location is posed in "raw weather" (Nabokov, 1955, p. 182) by a dangerously inquisitive neighbor, Miss Lebone: “and where is your mother, my dear?” (Nabokov, 1955, p. 182). It is Miss Lebone who overhears a loud quarrel between Lolita and Humbert and Lolita accuses Humbert of mudering her mother (Nabokov, 1955, p. 207). Later, Miss Lebone’s complaint by telephone enables Lolita to “escape” to a telephone booth, where, under a “tepid rain”, Lolita agrees with Quilty to deceive Humbert across much of America. Lolita hangs up and tells Humbert that a "great decision" has been made, and he notices that “the rain had become a voluptuous shower” (Nabokov, 1955, p. 209).

Not long after Miss Lebone’s question about Lolita's mother, Humbert has a conversation with Miss Pratt, who asks him about Charlotte’s religion: "by the way, Mr. Haze, her mother was” (Nabokov, 1955, p. 196). She also asks Humbert if his "poor wife" (Nabokov, 1955, p. 196) had instructed Lolita in matters of sex. After this, Miss Pratt persuades Humbert to let Lolita take part in Quilty's play, which allows Quilty to have private "rehearsals" with Lolita.

Perhaps the best evidence that Charlotte's spirit is faintly promoting Quilty's increasingly successful intrusions upon Humbert is to be found in Humbert's sudden visions and somewhat hallucination recollections. In these, Humbert repeated sees the deceased Charlotte at times when the advantage leans to Quilty. Early in Part 
Two of the novel, for example, Humbert has a strange double vision: "for some reason", which is one of the typical spirit-induced vivid recollections, he says, "with a kind of icy vividness, [I] saw Charlotte's face in death, and I glanced around, and noticed Lo... in the company of a tall man who carried two tennis raquets" (Nabokov, 1955, p. 165).

Another example occurs later in their travels, when Humbert becomes aware "in the windy grayness" of Lolita’s “absence” (Nabokov, 1955, p. 213). Then "the sound of Charlotte’s last sob incongruously vibrated through me as ... Lolita veered from a totally unexpected direction” (Nabokov, 1955, p. 213). Lolita has just met Quilty at a nearby gas station. Humbert's recollection of deceased Charlotte, as in his double vision, is therefore not as "incongruous" as he thinks. After this, they drive to Kasbeam, and although Humbert "refused to be diverted by the feeling of well-being that my walk had engendered-by the young summer breeze that enveloped the nape of my neck” (Nabokov, 1955, p. 216), Lolita deceives him with Quilty as planned.

They drive on, through "a number of great thunderstorms" (Nabokov, 1955, p. 218). Or perhaps, Humbert adds, there was only "one single storm ... which we could not shake off just as we could not shake off detective Trapp” (Nabokov, 1955, p. 218). Here, the persistent storms are explicitly associated with Quilty's haunting of Humbert and Lolita or with Charlotte's spirit which is attempting to promote Quilty's tenacious pursuit. Humbert soon declares: "as happens with me at periods of electrical disturbance and crepitating lightning, I had hallucinations. Maybe they were more than hallucinations" (Nabokov, 1955, p. 219). Here, Humbert tells us that "through torrents of rain" he "kept seeing that read ghost" (Nabokov, 1955, p. 219). Ironically, the "ghost" is in the rain and the read car which contains Quilty, with whom Lolita furtively plots in the same paragraph. Then, questioned by a suspicious Humbert, Lolita says "Perhaps he is Trapp” (Nabokov, 1955, p. 221) and abruptly changes the subject to the car's speedometer and to her deceased mother. Humert observes that this was "the first time" (Nabokov, 1955, p. 221) that Lolita had spoken "spontaneously" (Nabokov, 1955, p. 221) of her "pre-Humbertian childhood". However, he fails to discern that Lolita is actimg in further developing his own pattern of recalling deceased Charlotte at times when Quilty triumphs.

The "red ghost" of Quilty's car, we may recall, had made room for Humbert and Lolita when whey first drove up to The Enchanted Hunters. The car was then termed "rubous in lighted rain” (Nabokov, 1955, p. 119), subtly associating Charlotte's spirit with Quilty. The word "rubous" was later corrected to "rubious" which means "ruby-like”. Later when Lolita arrives home suspiciously late (Nabokov, 1955, p. 194), Humbert abruptly remarks that he was "always strangely disturbed" by a "small cobwebby casement window ... glazed with ruby" (p. 194). Presumably, Humbert is now “strangely disturbed” (Nabokov, 1955, p. 194) between Charlotte’s spirit has faintly promoted a rendezvous between Lolita and Quilty.

When Humbert finally visits Lolita to learn that "Trapp” was Quilty, he arrives in a "drizzle” (Nabokov, 1955, p. 271), which blends with his tears as he leaves (Nabokov, 1955, p. 282). After Lolita reveals Quilty's identity, she smokes: "gracefully, in a blue mist, Charlotte Haze rose from her grave, I would find him through Uncle Ivory is she refused” (Nabokov, 1955, p. 277). "him” refers to Quilty, whose address Humbert has just requested. Ostensibly, Charlotte’s ghost appears because Lolita smokes "like her mother” (Nabokov, 1955, p. 277). As we can suspect that Charlotte's spirit is presumably concerned that Humbert now seeks information to kill Quilty. And it is thus appropriate that Humbert, on the way to kill Quity, is "accompanied" by a “thunderstorm” (Nabokov, 1955, p. 295). 
Before obtaining Quilty's address from Ivor, Humbert walks in the Ramsdale cemetery and jokingly greets Charlotte's ghost: "Bonzhur, charlotte" (Nabokov, 1955, p. 289). After this, feeling that he is "losing time" (Nabokov, 1955, p. 291), Humbert takes a hotel room and goes down to the bar, which has a "garnet-red light that in Europe years ago went with low haunts” (Nabokov, 1955, p. 291). In the next sentence, Humbert recalls sitting at the "same little table" (Nabokov, 1955, p. 291) with Charlotte. Charlotte’s spirit seems attempted to delay Humbert's plan to murder Quilty through the weird "losing time” (Nabokov, 1955, p. 291). Humbert's vivid recollection of Charlotte and his joking about her ghost form part of the overall pattern tending to confirm this; his sitting at that "same little table" (Nabokov, 1955, p. 291) thus seems faintly eerie.

When Humbert finally attempts to kill Quilty, we are given what is perhaps the most eerie evidence of the influence of charlotte's spirit. First, Humbert impossibly realized that "far from killing him was injecting spurts of energy into the poor fellow, as if the bullets had been capsules wherein a heady elixir danced” (Nabokov, 1955, p. 305). Humbert then shoots Quilty again, “at very close range”, whereupon he tells us : "I may have lost contact with reality for a second or two ... a kind of momentary shift occurred as if I were in a connubial bedroom, and Charlotte were sick in bed" (Nabokov, 1955, p. 305). After this, Humbert discovers that he is holding one of Quilty's slippers instead of the pistol. As with Humbert's vision of “Charlotte’s face in death” (Nabokov, 1955, p. 305), his recollection of her "last sob" and her risimg "from the grave” (Nabokov, 1955, p. 305) deceased Charlotte’s sudden appearance "in bed” here suggests an effort to help Quilty.

Not long after Quilty dies, his spirit may be seen to join the conspiracy against Humbert. Driving away from the murder scene, Humbert jokingly refers to Quilty's ghost (Nabokov, 1955, p. 308), much in the same way as he had preciously envisioned Charlotte's ghost and addressed it in her afterlife. He then similarly fails to detect Quilty’s spectral influence a few lines later. It suddenly occurred to him, Humbert says, "as a novel experience", to drive on the wrong side of the road "in a way, it was a very spiritual itch" (Nabokov, 1955, p. 308). Taken literally, this statement becomes a Nabokovian character's typically unwitting indication of ghostly influence. "In a way” that Humbert fails to discern, his sudden inspiration was indeed “a very spiritual itch” (Nabokov, 1955, p. 308) because Quilty has thus spectrally promoted Humbert's capture, which occurs within a few lines. At the end of Despair, Hermann unwittingly and quite similarly suggests in his narration that his capture is being promoted by the ghost of the man he has murdered.

In Lolita, Charlotte concentrates her influence on Humbert through Quilty or induces dreams and recollections which cause Humbert to remember he former self. Just as Nabokov has admitted that his diverse books are very similar in many ways and several of the apparently isolated ideas about ghosts or whatever in his individual works instructively apply to others. Charlotte's spirit influences Quilty in strikingly much the same way that Mira’s spirit, who appears through wind in Pnin, influences Dr. Wind, who deprives Pnin of Liza.

\section{Sign Decoding of Nabokovian Otherworld}

The presence and influence of the ghosts are subtly confirmed by a complex system of encoded ways. Numerous casual, sarcastic, or joking references to ghosts, specters, spirits, shades, etc. reveal strikingly truth if taken seriously. Not only are the names of the ghosts sometimes hidden in the text when they appear, but also there is often a highly suggestive relationship between the names of the spirits and of the people they influence. 
In Lolita, Charlotte acts through the highly suggestive weather, such as wind, rain as well as via some living person, such as Clare Quility. In Pale Fire, these after-life beings concentrate their influence more on some particular substantial agency. Particularly speaking, Oleg exerts influence on Kinbote via electricity and Aunt Maud warns Shade through butterfly.

Just as the title suggests, it might be regarded as a book related with lighting. In Pale Fire, survival after death and coping with the hereafter are central concerns of John Shade’s poem "Pale Fire”. He also wrote a poem devoted to suggesting that the dead live on in various forms of electricity. It thus seems quite ironic that both Shade and his commentator Kinbote fail to interpret ghostly presences and influences via electricity throughout the novel. And these glowing ghostly manifestations may be seen to develop a special additional dimension of Pale Fire itself.

King Charles escapes from the palace where he is held prisoner in Zembla because he happens to remember exploring a secret passageway with his boyhood friend Oleg, who had died many years before (Nabokov, 1989, p. 92) and helps the king to recall the passageway. Oleg's spirit may be seen to act through electricity exactly as outlined in Shade's poem.

"The Nature of Electricity" suggests that spirits of the dead may live on in three places: bedside lamps, streetlamps, and lightning (Nabokov, 1989, p. 138). And all three media of Shade's poem are associated with King Charles' recollection. A streetlamp, Shade declares in the poem, may be "an old friend of mine", who is highly suggestive of Oleg, attracting "the pale moths of starless nights". Just before the King recalls the passageway, we read: "the summer night was starless ... with distant spasms of silent lightning. Around the lantern that stood on the bench a moth blindly flapped” (Nabokov, 1989, p. 88). After this, King Charles' "bedside light" puts "a bright gleam on the gilt key in the lock of the closet door. And all at once that spark on that key caused a wonderful conflagration to spread in the prisoner's mind” (Nabokov, 1989, p. 88). Thus the King recalls the secret passageway and escapes.

When King Charles begins to escape, "distant lightning still throbbed now and then in the window" (Nabokov, 1989, p. 96). In the passageway, he turns on an electric torch: "the dim light he discharged at last was now his dearest companion, Oleg’s ghost, the phantom of freedom” (Nabokov, 1989, p. 96) later, emerging from the passageway into the theater, King Charles is helped by his friend Odon to escape. Oleg's spirit seems to oversee this as well, for as the King and Odon safely separate, we read: "a handshake, a flash of lightning” (Nabokov, 1989, p. 100). Oleg's spirit may even help the King to find refuge at a farmer's cottage that night. About to give up and stop on a dark mountain slope, the King sees that "all at once a pinhead of light gleamed ahead" (Nabokov, 1989, p. 101). Another clue is that "a phantom companion" (Nabokov, 1989, p. 166) is associated with the King's escape in the mountains, and "Oleg's ghost”, in the passageway, was synonymous with "the phantom of freedom" (Nabokov, 1989, p. 166). Finally, Oleg's concerned spirit may even be involved with the "formidable thunderstorm" (Nabokov, 1989, p. 192) that Gradus "had never seen such a display of lihgtning" (Nabokov, 1989, p. 192) when he arrives to kill the King. All those images of lightning, streetlamps, bedlamp, "gleam” on key, "dim light" of electric torch, and "gleam” of pinhead light seem to fit the ghostly presence and influence of "pale fire" mentioned above.

A more obvious manifestation of ghostly pale fire may be found in "The Haunted Bard" (Nabokov, 1989, p. 136). Despite Shade's suspicion that spirits reside in electricity, he never realizes that "a roundlet of pale fire” 
(Nabokov, 1989, p. 136) spells out, following an electric storm, a message that warns of his impending death. The letters "not ogo old wart" (Nabokov, 1989, p. 135) can be read "not to go Goldworth", and Shade is later killed when he goes to Goldworth's house and the warning in the barn can be deduced as Shade's Aunt Maud's spirit. He tells us in "Pale Fire" that he "was brought up by dear bizarre Aunt Maud" and that she liked to paint pictures with "images of doom” (Nabokov, 1989, lines 86-89).

Besides electricity, Nabokov has made the most extensive use of butterfly to suggest ghostly presence and influence. In particular, butterfly can be seen as another clue to prove that Maud's spirit makes a last and desperate attempt to warn Shade’s death as he "goes to Goldworth's".

In Kinbote's words, "a Red Admirable” butterfly "came dizzily whirling around us like a colored flame” (Nabokov, 1989, p. 204) just “one minute before” Shade’s death. This "rapid butterfly”, says Kinbote, “...flashed and vanished, and flashed again, with an almost frightening imitation of conscious play which now culminated in its settling upon my delighted friend's sleeve” (Nabokov, 1989, p. 204). Here Kinbote is so near and so close to detect the influence of Maud's spirit. Maud, as mentioned above, painted "images of doom", and Kinbote tells us that Shade "pointed out” the Red Admirable "to me as he walked to his doom” (Nabokov, 1989, p. 123). We are also told that Shade had the habit of "pointing out" to Kinbote "with the tip of his cane various curious natural objects" (Nabokov, 1989, p. 121). This is presumably the "sturdy cane that had belonged to his Aunt Maud” (Nabokov, 1989, p. 17). And since Shade also pokes “with Aunt Maud's favorite cane” at the spot where the old barn had stood (Nabokov, 1989, p. 133), we may conclude that he twice unwittingly points out the influence $f$ Maud's spirit with her own cane.

In Nabokov's Strong Opinions, Nabokov explains that the Red Admirable was called "The Butterfly of Doom” in Northern Russia, and "was especially abundant in 1881, the year Tsar Alexander II was assassinated, and the markings on the underside of its two wings seem to read '1881'”' (Nabokov, 1973, p. 170). Since Maud had liked to paint "images of doom", it seems logical that her spirit would use this butterfly to try to warn Shade. Moreover, butterfly and moths are typically used as vehicles by the spirits of Nabokovian characters who had been involved with these creatures while alive. In a draft version of Shade's poem, he wrote of Maud: "her trivia for us / Retrace her style: the leaf sarcophagus / (A Luna’s dead and shriveled-up cocoon)” (Nabokov, 1973, p. 82). Judging form the final text, the word "style" was apparently intended by Shade to mean Maud's manner of painting. As we can see, however, it was also her "style", following an interest in Luna moths while alive, to appear after death via a butterfly of doom as the kind of image of doom that she had liked to paint.

In the final version of "Pale Fire", Shade writes: "The Toothwort White haunted our woods in May" (Nabokov, 1989, line 316). Kinbote is unsure of the meaning here, but he offers that the non white can mean "a certain genus of lepidoptera” (Nabokov, 1989, p. 131). Early in Shade’s poem, he describes white butterflies at sunset near his favorite young shagbark tree (Nabokov, 1989, lines 49-50). After Hazel's death, shade declares that he "knew" that "...no phantom would / Rise gracefully to welcome you and me / in the dark garden, near the shagbark tree" (Nabokov, 1989, lines 650-652). Here Shade's words teasingly miss the truth. The phantom, acting through a butterfly, is not Hazel's haunting spirit but Maud's, and it appears near the shagbark tree at the end of Shade's poem in a passage that unwittingly previsions the butterfly scene that occurs "one minute before" Shade's death. Having mentioned the shagbark tree, Shade writes: "A dark Vanessa with a crimson band / Wheels in the low sun, settles on the sand” (Nabokov, 1989, lines 993-994). As Kinbote tells us, the Vanessa 
butterfly (pictured in the poem) is anther name for the Red Admirable (seen one minute before Shade's death,) which they had seen before "on the same spot” (Nabokov, 1989, p. 204). The Vanessa in Shade's poem is thus his recollection of the butterfly through which Maud's spirit acts. In the poem, Shade mentions "a man, unheedful of the butterfly" (Nabokov, 1989, line 997) whom he takes for a gardener but who later becomes the poet himself as he fails to heed Maud's spirit's warning in the scene he unwittingly predicts. Another detail is "the low sun" which is often attending suggestions of ghosts in Nabokov's works. Kinbote later associates "the low sun" (Nabokov, 1989, p. 204) with the Red Admirable that lands on Shade's sleeve one minute before he dies.

\section{Aesthetic Ethics of Nabokovian Otherworld}

Nabokov's preoccupation with the otherworld, which gives rise to controversy in criticism. Donald E. Morton argues that Nabokov stresses too much on subjectivity, which makes his characters "sound like solipsists, like individuals completely wrapped up in their own mental worlds. It is as if they have no sense of the objective existence of an outer reality" (Morton, 1974, p. 11). Jonathan Raban deems that his English is a shaky blend of grammarian's pedantry slang and the language of the novel is a hyperactive mongrel of English, French and Russian. Many Russian critics deem that Nabokov pays no interest in the social, political, moral or philosophical themes and ignores the writer's obligation to address existing, real problem. At the opposite extreme are contemporary critics in the United States and Europe who see Nabokov's insistent artificiality as a defense of the artist's free creativity in the face of a hostile, indifferent, chaotic or valueless world. Charles Rolo extols him as "the most original writer" since Joyce (Rolo, 1958, p. 78).

Nabovian otherworld, a combination of his aesthetic, metaphysical and moral view, which resists easy interpretation. Most Nabokovian ghosts have motivations logically extending from their lives and the circumstances of their death. Some are vengeful such as Charlotte's and some are compassionate and loving such as Oleg's and Maud's. A Nabokovian ghost may seem quite unpleasant if imagined by the living. Humbert's speculation is one of the most extreme: "the hereafter" for all we know may be an eternal state of excruciating insanity” (Nabokov, 1955, p. 299). In Lolita's words, "what's so dreadful about dying is that you are completely on your own” (Nabokov, 1955, p. 286).

Yet, Nabokovian ghosts may welcome the pleasure of detecting patterns while moving freely throughout the present and the past. As Boyd has observed: "Nabokov always envisages that human, mortal memory might be the forerunner of a consciousness, which could endlessly reinvestigate the past, discovering new patterns and new harmonies” (Boyd, 1979, p. 605). This is strongly suggestive in Speak Memory. Becoming his ghost, Nabokov reinvestigates the past as endlessly as mortal memory will allow. As his own ghost, he searches his life for "thematic designs" (Nabokov, 1955, p. 27), which he terms "the true purpose of autobiography”. In this sense, Nabokov actually becomes his own "ghostly envoy" (Nabokov, 1955, p. 98); he is, as he puts it, "the discarnate carrier of my present reminiscences” (Nabokov, 1955, p. 138).

E. M. Forster holds that "once in the realm of the fictitious, what difference is there between an apparition and a mortgage” (Forster, 1976, p. 103). For Nabokov, he has somewhat declared that despite the seemingly ability of science to pierce mysteries, "the situation remains as hopeless as ever" (Nabokov, 1973, p. 44). Asked then if he believed in God, Nabokov replied: "I know more that I can express in words, and the little I can express would not have been expressed, had I not known more” (Nabokov, 1973, p. 45). As he explained in an interview, 
I work hard, I work long, on a body of words until it grants me complete possession and pleasure. If the reader has to work in his turn-so much the better. Art is difficult. Easy art is what you see at modern exhibitions of things and doodles. (Nabokov, 1973, p. 115)

Whatever is easily accomplished or understood by all, whatever is popular, or a commonplace, naturally and automatically risks falsehood. This was for Nabokov a fundamental insight rooted in his experience of life. In Lolita and Pale Fire, Nabokov created the kind of "difficult” fiction that French critic in this way Barthes defines as a "text of bliss", which "imposes a state of loss, the text that discomforts, unsettles the reader's historical, cultural, psychological assumptions, the consistency of his tastes, values, memories, brings to a crisis his relation with language” (Barthes, 1977, p. 10).

Nabokov's mad Kinbote describes "God's Presence” as follows: “a faint phosphorescence at first, a pale light in the dimness of bodily life, and a dazzling radiance after it” (Nabokov, 1989, p. 161). For Kinbote, God thus resembles a perfectly evolved radiance independent of time. Nabokov himself has more cautiously speculated: "time without consciousness-low animal world; time with consciousness man; consciousness without time—-some still higher state” (Nabokov, 1974, p. 30). The author, as a Creator who can turn backwards and forwards at will the file cards upon which he composes, similarly transcends the time of his characters' world. To some extent, the author's own time can be compared to his characters' hereafter.

"What I really like about the better kind of colloquy", Nabokov once explained in an interview, "is the opportunity it affords me to construct in the presence of my audience the semblance of what I hope s a plausible and not altogether displeasing personality” (Nabokov, 1974, p. 158). Many readers have focused only on the aloof, self-confident and mocking side of Nabokov's personality and have neglected what is humane, witty, and noble in it, such a reading is unfair to Nabokov because he was a confirmed elitist only in the sense that he prized highly the difficulty and skill inherently in creating or grasping anything of value.

\section{Conclusion}

Under the principle of “text of bliss” lies in Nabokov's unique aesthetic humanism. In most general terms, Nabokov's characteristic aesthetic practices resurrect the Romantic idea that the artist is God's rival, and that man's artistic creations are analogues to God's natural world. Nabokov was obviously aware of this conception, as he revealed when he stated in a lecture that "art is a divine game ... because this is the element in which man comes nearest to God through becoming the true creator in his own right” (Nabokov, 1974, p. 158).

Nabokov is highly acclaimed as one of the finest stylists and greatest novelists in American literature, both for the daring originality of his conceptions and for the meticulous strategies to realize them. Harold Bloom holds that where Nabokov can hardly be overprized is in his achievement as a stylist. John Updike confidently praises him "the most important American writer" since Faulkner (Proffer, 1982, p. 51). Updike argues that, in the intensity of its intelligence and reflective joy, his fiction was unique and scarcely precedent in American literature of his time. Nabokov's brilliant experiment with the subjects of afterlife deserves appropriate appraisal, because it offers new possibilities and combinations for the exhausted genre of the novel, uses its fragmented status to compel the reader to take an active role in the creation of the text, challenges the modernist view of art as the autonomous expression of individual subjectivity, presents a Chinese box view of reality and fiction that subverts any attempt to arrive at a comprehensive reading, redefines the novel as an elaborate, multilevel 
acrostic, revives the romantic attempt to seal up the split between subject and object of America and Europe in the 1960s.

\section{References}

Abraham, N. (1987). Notes on the phantom: A complement to Freud's metapsychology. (N. Rand, Trans.). Critical Inquiry, 13(2), 287-292.

Barthes, R. (1977). The death of the author. In S. Heath (Ed.), Image-music-text (pp. 9-16). London: Fontana Press.

Boyd, B. D. (1979). Nabokov and Ada (Ph.D. thesis, University of Toronto).

Derrida, J. (1994). Spectres of Marx: The state of the debt, the work of mourning, and the new international. (P. Kamuf, Trans.). New York: Routtledge.

Forster, E. M. (1976). Aspects of the novel. Harmondsworth: Penguin.

Morton, D. E. (1974). Vladimir Nabokov. New York: Frederick Ungar Publishing.

Nabokov, V. (1979a). Despair. New York: G. P. Putnam’s Sons.

Nabokov, V. (1979b). Foreword to Nabokov's Stikhi. Ann Arbor: Ardis.

Nabokov, V. (1980). Lectures on literature (edited by F. Bowers, introduced by J. Updike). New York and London: Harcourt Brace Jovanovich/ Bruccoli Clark.

Nabokov, V. (1955). Lolita. New York: Putnam’s.

Nabokov, V. (1989). Pale fire. New York: Vintage International.

Nabokov, V. (1970). Poems and problems. New York: McGraw-Hill Book Company.

Nabokov, V. (1989). Speak memory: An autobiography revised. New York: Vintage International.

Nabokov, V. (1973). Strong opinions. New York: McGraw-Hill International.

Proffer, C. R. (1982). The double life of Vladimir Nabokov. In Richard Kestelanetz (Ed.), American writing today (pp. 51-61). Washington, D.C.: U.S. International Communication Agency.

Rolo, C. (1958). A review of Lolita. The Atlantic Monthly, 202(3), 77-78.

Santag, S. (1992). Against interpretation. In P. Waugh (Ed.), Postmodernism: A reader today (pp. 51-58). London: Edward Arnold.

\section{Appendix A: Brief biography}

Dr. Juan Wu mainly engages in the study of English Literature and Literary Theory, Cultural Studies, Comparative Mythology, is a lecturer at School of Foreign Language, Beijing Institute of Technology and an academic visitor of Faculty of English Language and Literature, University of Oxford (2015-2016). She has authored Vladimir Nabokov: “A Rigid Moralisr” and numerous articles on academic journals. Recently she focuses on the retelling of myth in the postmodern sign economy and archetypal criticism of chinese jade mythology. 